\title{
Radiographic evaluation of cardiac silhouette in healthy Maine Coon cats
}

\section{Avaliação radiográfica da silhueta cardíaca de gatos sadios da raça Maine Coon}

\author{
Caio Sabino de Oliveira'; Ana Carolina Brandão de Campos Fonseca Pinto²; \\ Paula Hiromi Itikawa ${ }^{3}$; Francisco Ferreira Lima Júnior ${ }^{4}$; \\ Guilherme Teixeira Goldfeder ${ }^{5}$; Maria Helena Matiko Akao Larsson ${ }^{6 *}$
}

\begin{abstract}
Determining the size of the heart is important for evaluating cardiac patients, because the increase of the cardiac silhouette in the chest radiography can be indicative of heart disease. The vertebral heart size (VHS) method is useful because it allows objective assessment of the limits of cardiac silhouette, and can help assess cardiomegaly and document changes in heart size in response to treatment or disease progression. The aim of this study was to compare VHS values of Maine Coon cats (MCC) with values cited in the literature ( $7.5 \pm 0.3$ vertebrae) obtained in non Maine Coon cats (NMCC). Sixty three MCC underwent the physical examination, electrocardiography, echocardiography, laboratory tests (blood count, biochemistry, including liver and kidney function, and total $\mathrm{T}_{4}$ ), as well as measurement of blood pressure. Faced with normal results, the cats were positioned in right lateral decubitus (right laterallateral projection), to perform chest radiography. The radiographic examinations were performed using the Fuji computed radiography system. The values of VHS found in the animals of this study were 7.61 \pm 0.34 vertebrae with a minimum of 6.9 and of maximum 8.5 vertebrae. Statistical analysis performed by Student's $t$ test identified a significant difference between the values obtained in this study with those in the literature $(\mathrm{p}=0.03)$ for non Maine Coon cats. The highest values of VHS obtained in MCC may be associated with the size of this giant breed.
\end{abstract}

Key words: Feline, VHS, image, heart

\section{Resumo}

A determinação do tamanho do coração é importante na avaliação de pacientes cardiopatas, pois o aumento da silhueta cardíaca, na radiografia torácica, pode ser indicativa de enfermidade cardíaca. $\mathrm{O}$ sistema VHS (vertebral heart size) é util porque permite avaliar, objetivamente, os limites da silhueta cardíaca, auxiliando na avaliação de cardiomegalia e documentando alterações do tamanho cardíaco

\footnotetext{
${ }^{1}$ Discente de Mestrado, Faculdade de Medicina Veterinária e Zootecnia, USP, São Paulo, SP, Brasil. E-mail: caio.sabino.oliveira@ gmail.com

${ }^{2}$ Prof $^{\mathrm{a}} \mathrm{Dr}^{\mathrm{a}}$, USP, São Paulo, SP. E-mail: anacarol@usp.br

${ }^{3}$ Discente de Doutorado, M.e em Ciências, Faculdade de Medicina Veterinária e Zootecnia, USP, São Paulo, SP, Brasil. E-mail: paulaitikawa@gmail.com

${ }^{4}$ Discente de Doutorado, Faculdade de Medicina Veterinária e Zootecnia, USP, São Paulo, SP, Brasil. E-mail: guerreirovet@ hotmail.com

${ }^{5}$ Veterinário contratado, Faculdade de Medicina Veterinária e Zootecnia, USP, São Paulo, SP, Brasil. E-mail: guigagold@hotmail. com

${ }^{6}$ Prof ${ }^{a}$ Titular, Faculdade de Medicina Veterinária e Zootecnia, USP, São Paulo, SP, Brasil. E-mail: akaolar@usp.br

* Author for correspondence
} 
em resposta ao tratamento ou à progressão da doença. $\mathrm{O}$ objetivo deste trabalho foi comparar valores de VHS de gatos Maine Coon (GMC) sadios com aqueles citados na literatura (7,5 $\pm 0,3$ vértebras) obtidos de gatos não Maine Coon (GNMC). Sessenta e três GMC foram avaliados por meio de exames físico, eletrocardiográfico, ecocardiográfico, laboratoriais (hemograma, funções hepática e renal, $\mathrm{T}_{4}$ total), bem como pela determinação da pressão arterial. Frente a resultados normais, os animais foram posicionados em decúbito lateral direito (projeção látero-lateral direita), para realização da radiografia torácica, realizada utilizando o sistema Fuji de radiografia computadorizada. Os valores de VHS obtidos neste trabalho foram 7,61 $\pm 0,34$ vértebras, com mínimo de 6,9 e máximo de 8,5 vértebras. A análise estatística realizada pelo teste $t$ de Student mostrou diferença significativa entre os valores ora obtidos em relação àqueles citados na literatura $(\mathrm{p}=0.03)$ para gatos não Maine Coon. Os valores de VHS maiores observados em GMC podem estar associados com o porte gigante desta raça de gatos.

Palavras-chave: Felino, VHS, imagem, coração

\section{Introduction}

Cardiomyopathies are the most common forms of heart disease seen in cats (FERASIN, 2012). These patients exhibit a wide spectrum of functional and structural heart abnormalities, resulting in different patterns of increase in the cardiac silhouette (HAMLIN; SMETZER; SMITH, 1963; HARPSTER, 1977). According to Buchanan and Bücheler (1995), chest x-rays may suggest the prognosis and therapy to be instituted by serving as a means of monitoring the development of heart disease. Radiographically, the cardiac silhouette of felines tends to be more elliptical and elongated compared to the canines. In both species, it was observed that ventricular area of the heart occupies approximately 2.0 to 2.5 intercostal spaces and that the heart silhouette fills approximately $70 \%$ of the distance from the sternum to the spinal column, through the longitudinal axis of the heart in laterolateral projection (MYER; BONAGURA, 1982).

It is known that, even in healthy hearts radiographs, there are shadow formations, which have acceptable limits, in order to detect changes in morphology, such as changes in large vessels or chambers, which can indicate which type of injury affects the organ (HAMLIN; SMETZER; SMITH, 1963).

The correct positioning is mandatory to analyse the size and morfology of the cardiac silhouette in radiographic images. Based on the presence of a bulge related to a specific area in an image of good quality it is possible to assess cardiac enlargements and identify which chamber is compromised.

The determination of the heart size is important in the evaluation of cardiac patients, because the enlarged cardiac silhouette and radiographic signs may be indicative of heart disease. The vertebral heart size (VHS) method is easy to be used because it allows objective assessment of cardiac size, assisting in the determination of cardiomegaly, and is also a convenient way to document changes in heart size in response to treatment or progression of heart disease (BUCHANAN, 2000). The present study aimed to compare the VHS measures of Maine Coon cats (MCC) with those standardized by Buchanan (2000) in non Maine Coon cats (NMCC).

\section{Materials and Methods}

Fifty eight Maine Coon cats from the city of São Paulo and surrounding counties were evaluated from February 2009 to October 2011 at the Cardiology Unit (Serviço de Cardiologia) in the Department of Internal Medicine (Departamento de Clínica Médica, VCM) of the Veterinary Hospital (Hospital Veterinário, HOVET) at the School of Veterinary Medicine and Animal Science of the University of São Paulo (Faculdade de Medicina Veterinária e Zootecnia da Universidade de São Paulo, FMVZ$U S P)$. Each patient owner signed a consent form prepared by the researchers involved. 
Physical examination, electrocardiography (eletrocardiógrafo ECAFIX ECG 6, Transform, São Paulo, SP), echocardiography (Vivid 7, GE Vingmed Ultrasound AS, Horten, Norway) and measurement of blood pressure by Doppler method (Doppler Vascular DV610B, Medmega, Franca, SP) were done at Cardiology Unit. Laboratory tests (blood count, biochemical serum total albumin, ALT, AST, $\mathrm{AF}$, urea, creatinine) was performed at the Clinical Laboratory of the VCM/HOVET/FMVZ/USP. Total $\mathrm{T}_{4}$ determination was performed at Laboratório de Dosagens Hormonais do Provet, Instituto Brasileiro. de Diagnóstico e. Especialidades Veterinárias. Ltda, São Paulo, SP. Faced with normal results, chest radiographs were performed.

Echocardiographic examinations were performed with commercial apparatus, according to the recommendations of Echocardiography Committee of the Specialty of Cardiology -
American College of Veterinary Internal Medicine (THOMAS et al., 1993) and the American Society of Echocardiography (ASE), with adaptations suggested by Boon (1998). Electrocardiographic exam was interpreted according to Goodwin (2001).

Computed radiographic system (FUJI) and a high frequency $(500 \mathrm{~mA}$ e $125 \mathrm{kVp})$ radiographic equipment (Fujifilm Medical Corporation, Tokyo, Japan), with a Potter-Bucky grid were used to obtain the thoracic radiographs in right lateral, left lateral and ventro-dorsal views. The exams were performed without sedation with standart exposure techniques respecting the ALARA (As Low As Reasonably Archivable) principles. To proceed the qualitative and quantitative analyses of the images a dedicated workstation was used (HENDEE; EDWARDS, 1986). The evaluation of the cardiac silhouette was done according to Buchanan and Bücheler (1995) called VHS technique (Figure 1).

Figure 1. Digital radiography of the chest of a Maine Coon cat (GMC), illustrating the method of measuring VHS (vertebral heart size), with a value of 7.5 vertebrae. The long axis (pink line), short axis (orange line), demonstrating the methodology proposed by Buchanan and Bücheler (1995). Source: Department of Diagnostic Imaging HOVETFMVZ-USP, 2012.

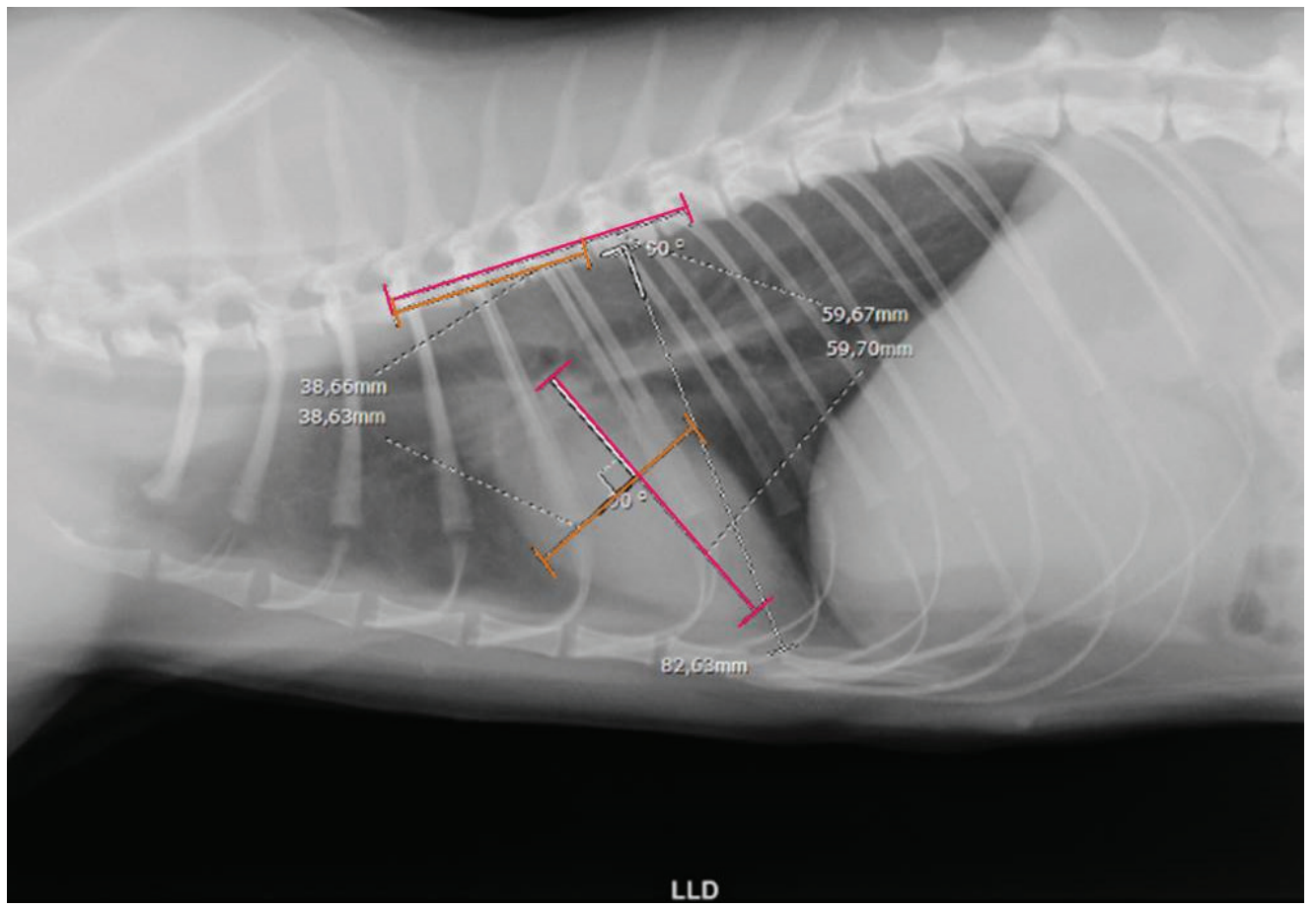

Source: Elaboration of the authors. 
The results obtained in this study is presented as mean and standard deviation, and the statistical analysis was performed using a commercial program (GraphPad-Instat, versão 3.01, GraphPad Software Inc., San Diego,

CA), in which we used the Student $t$ test, with significance level of $5 \%(\mathrm{p}<0.05)$, according to Arango (2005).

\section{Results}

In this study, 63 healthy adult Maine Coon cats being 22 males $(36.2 \%)$ and 41 females $(63.8 \%)$, with mean age of 40 months, ranging from 18 to 114 months, were evaluated. The average weight was found to be $5.25 \pm 1.23 \mathrm{~kg}$ ( 3.1 to $7.9 \mathrm{~kg}$ ).

The values of VHS found in this study were $7.61 \pm$ 0.34 vertebrae with a minimum of 6.9 and maximum of 8.5 vertebrae. Statistical analysis performed by Student's $t$ test identified a significant difference between the values obtained in this study and those of non Maine Coon cats $(\mathrm{p}=0.03)$ (Figure 2).

Figure 2. Values of vertebral heart size (VHS) in Maine Coon cats (GMC) compared to values in on Maine Coon cats (NMCC) described by Buchanan (2000).

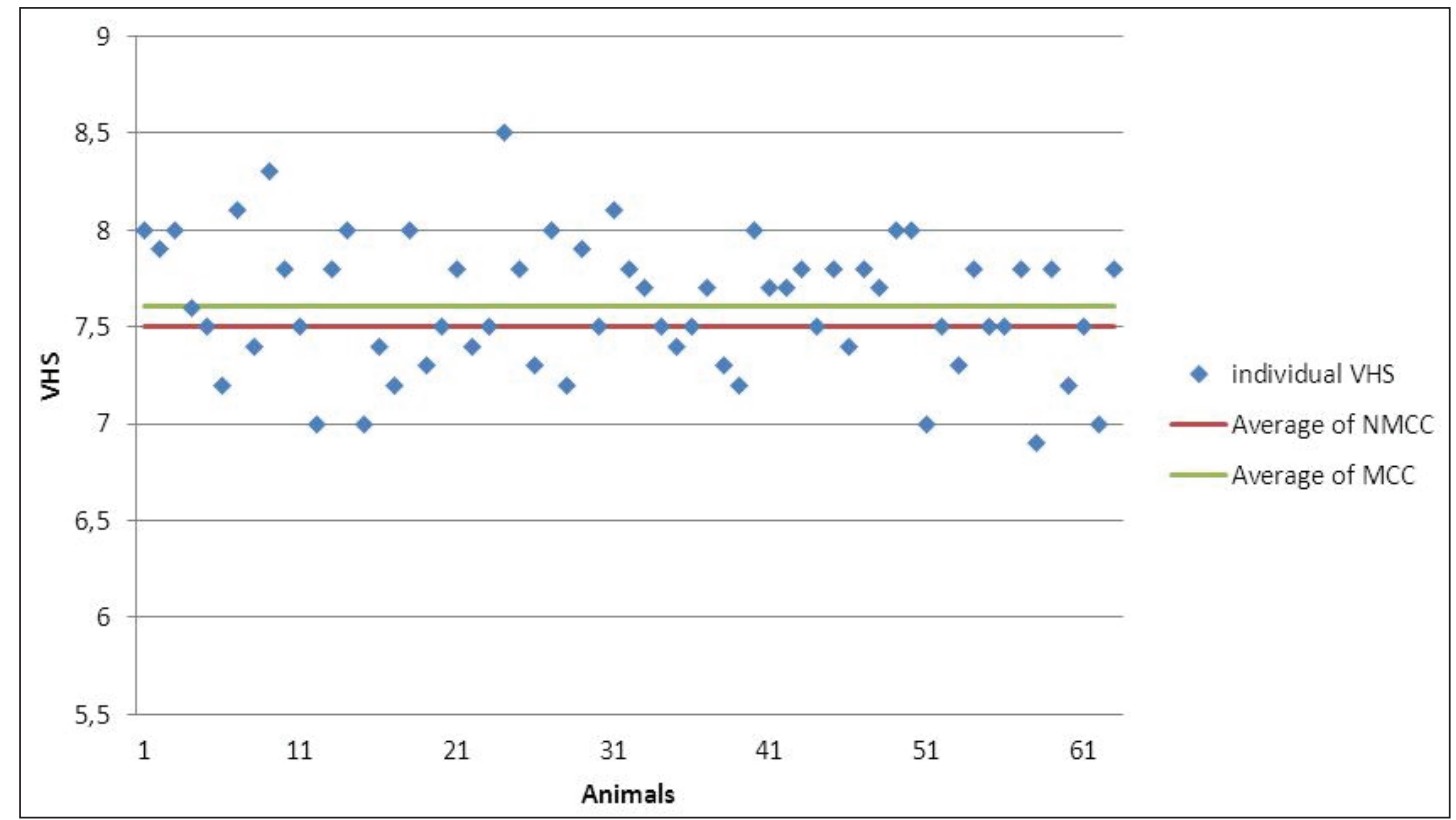

Source: Elaboration of the authors.

\section{Discussion}

The thoracic X-ray analysis revealed a greater definition of the cardiac silhouette in cats as compared to canines, which agrees with the description made by Van Den Broek and Darke (1987), or that cats, unlike dogs, have less variation in size and shape of the thorax, which allows better definition of cardiac measurements. Myer and Bonagura (1982) also reported that, radiographically, the feline cardiac silhouette tends to be more elliptical and elongated when compared to the canine one, fact confirmed in this study.

Kittleson (2004) and Ferasin (2009) also emphasized that hypertrophic cardiomyopathy can 
not be distinguished from other cardiomyopathies using only X-ray, because the definitive diagnosis is made by echocardiography. It is worth stressing that the respiratory phase, the cardiac cycle, positioning and measurements errors were described by Buchanan and Bücheler (1995) as possible causes of variability in the cardiac size evaluation.

According to Hamlin (1968) and Buchanan and Bücheler (1995), the dog heart size may vary with the size of the animal; thus, the highest VHS values obtained in Maine Coon VHS may be associated with the giant size of this feline breed.

It is important to emphasize that the analysis of radiographs by digital system allowed a better assessment, becoming possible to change the image properties such as contrast and brightness, allowing the examiner greater accuracy in its analysis.

\section{Conclusions}

VHS measures of MCC found in this study were higher when compared with the standard values of NMCC.

The highest values obtained in MCC VHS may be associated with the giant size of this breed.

\section{Ethics Committee}

This study was approved by the Ethics Committee on the use of animals FMVZ-USP, filed under No. $1739 / 2009$.

\section{Funding}

This study was funded by the Foundation for Research Support of the State of São Paulo (FAPESP)/process No. 09/54251-9 and by National Council of Scientific and Technological Development from Brazil (CNPq)/ process No. 119898/2009-8.

\section{References}

ARANGO, G. H. Bioestatística: teórica e computacional. 2. ed. Rio de Janeiro: Guanabara Koogan, 2005. 423 p.

BOON, J. A. Echocardiographic examination. In: (Ed.). Manual of veterinary echocardiography.

Baltimore: Williams \& Wilkins, 1998. p. 35-150.

BUCHANAN, J. W.; BÜCHELER, J. Vertebral scale system to measure canine heart size in radiographs. Journal of the American Veterinary Association, Schaumburg, v. 206, n. 2, p. 194-199, 1995.

BUCHANAN, J. W. Vertebral scale system to measure heart size in radiographs. Veterinary Clinics of North America: Small Animal Practice, Philadelphia, v. 30, n. 2, p. 379-393, 2000.

FERASIN, L. Companion animal practice: feline cardiomyopathy. In Practice, London, v. 34, n. 4, p. 204213, 2012.

Feline myocardial disease classification,

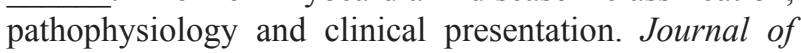
Feline Medicine and Surgery, Witshire, v. 11, n. 1, p. 183-194, 2009.

GOODWIN, J-K. Electrocardiography. In: TILLEY, L. P.; GOODWIN, J-K. Manual of canine and feline cardiology. $3^{\text {rd }}$ ed. Philadelphia: WB Saunders, 2001. p. 43-70.

HAMLIN, R. L. Analysis of the cardiac silhouette in dorsoventral radiographs from dogs with heart heart disease. Journal of the American Veterinary Association, Schaumburg, v. 153, n. 11, p. 1446-1460, 1968.

HAMLIN, R. L.; SMETZER, D. L.; SMITH, C. R. Radiographic anatomy of the normal cat heart. Journal of the American Veterinary Medical Association, New York, v. 143, n. 9, p. 957-961, 1963.

HARPSTER, N. K. Feline cardiomyopathy. Veterinary Clinics of North America: Small Animal Practice, Philadelphia, v. 7, n. 2, p. 355-371, 1977.

HENDEE, W. R.; EDWARDS, F. M. ALARA and an integrated approach to radiation protection. Seminars in Nuclear Medicine, New York, v. 16, n. 2, 142-150, 1986.

KITTLESON, M. D. Feline myocardial disease. In: ETTINGER, S. J.; FELDMAN, E. C. Textbook of veterinary internal medicine. 6. ed. Philadelphia: WB Saunders, 2004. p. 1082-1104.

MYER, C. W.; BONAGURA, J. A. Survey radiography of the heart. Veterinary Clinics of North America: Small Animal Practice, Philadelphia, v. 12, n. 2, p. 213-217, 1982. 
THOMAS, W. P.; GABER，C. E.; JACOB， G. J.; VAN DEN BROEK, A. H. M.; DARKE, P. G. G. Cardiac KAPLAN, P. M.; LOMBARD, C. W.; MOISE, N. measurements on thoracic radiographs of cats. Journal S.; MOSES, B. L. Recommendations for standards in transthoracic two-dimensional echocardiography in the Small Animal Practice, Malden, v. 28, n. 2, p. 125-135, dog and cat. Journal of Veterinary Internal Medicine, Malden, v. 7, n. 4, p. 247-252, 1993. 1987. 